\title{
Effect of Application Frequency and Reduced Rates of Acibenzolar-S-Methyl on the Field Efficacy of Induced Resistance Against Bacterial Spot on Tomato
}

\author{
Cheng-Hua Huang and Gary E. Vallad, Gulf Coast Research and Education Center, University of Florida, IFAS, Wimauma 33598; \\ Shouan Zhang, Tropical Research and Education Center, University of Florida, IFAS, Homestead 33031; Amin Wen, Department of \\ Plant Pathology, North Dakota State University, Fargo 58108; Botond Balogh, Jose Francisco L. Figueiredo, Franklin Behlau, \\ Jeffrey B. Jones, and M. Timur Momol, Department of Plant Pathology, University of Florida, Gainesville 32611; and Steve M. \\ Olson, North Florida Research and Education Center, University of Florida, Quincy 32351
}

\begin{abstract}
Huang, C.-H., Vallad, G. E., Zhang, S., Wen, A., Balogh, B., Figueiredo, J. F. L., Behlau, F., Jones, J. B., Momol, M. T., and Olson, S. M. 2012. Effect of application frequency and reduced rates of acibenzolar-S-methyl on the field efficacy of induced resistance against bacterial spot on tomato. Plant Dis. 96:221-227.

Acibenzolar-S-methyl (ASM), a plant activator known to induce systemic acquired resistance, has demonstrated an ability to manage a number of plant diseases, including bacterial spot on tomato caused by four distinct Xanthomonas spp. The aim of this study was to evaluate application rate and frequency of ASM in order to optimize field efficacy against bacterial spot in Florida, while minimizing its impact on marketable yields. ASM was applied biweekly (once every 2 weeks) as a foliar spray at a constant concentration of $12.9,64.5$, and $129 \mu \mathrm{M}$ throughout four field experiments during 2007-08. A standard copper program and an untreated control were also included. Overall, biweekly applications of ASM did not significantly reduce disease development or the final disease severity of bacterial spot compared with the copper-mancozeb standard or the untreated control. Only one experiment showed a significant reduction in the final disease severity on

plants treated with ASM at $129 \mu \mathrm{M}$ compared with the untreated control. Three additional field trials conducted during 2009-10 to evaluate the effects of weekly and biweekly applications of ASM at concentrations of 30.3 to $200 \mu \mathrm{M}$ found that weekly applications provided significantly better disease control than biweekly applications. The tomato yields were not statistically improved with the use of ASM relative to the untreated control and standard copper program. Weekly ASM applications at rates as low as $75 \mu \mathrm{M}$ (equivalent to $1.58 \mathrm{~g}$ a.i./ha in 100 liters of water or $0.21 \mathrm{oz}$. a.i./acre in 100 gallons of water) to $200 \mu \mathrm{M}$ (equivalent to $4.20 \mathrm{~g}$ a.i./ha in 100 liters of water or $0.56 \mathrm{oz}$. a.i./acre in 100 gallons of water) were statistically equivalent in managing bacterial spot of tomato without significantly reducing yield compared with the untreated control.
\end{abstract}

Bacterial spot, a destructive disease of tomato (Solanum lycopersicum) worldwide, is caused by at least four taxonomically distinct xanthomonads, including Xanthomonas euvesicatoria (T1), $X$. vesicatoria (T2), X. perforans (T3 and T4), and X. gardneri $(16,17,37)$. The disease results in leaf spots, defoliation, and fruit lesions (15). Although these four species cause similar symptoms that occur on all aboveground organs under high rainfall and high temperatures, lesions vary depending on environmental conditions and species of the pathogen (37). The lesions on fruit lead to nonmarketable tomato and, in turn, economic losses to tomato growers. The economic losses caused by bacterial spot have been estimated up to $50 \%$ of yield $(26,34)$, placing this disease as a top priority for research (27).

Although integrated management strategies have been evaluated over the years, management of bacterial spot on tomato has been one of the greatest challenges to tomato growers. Seed treatments have been used to eliminate seedborne inoculum since the early 1920s (8) but they are insufficient to eliminate disease development in the field or the potential movement of strains (37). Other

\section{Corresponding author: G. E. Vallad, E-mail: gvallad@ufl.edu}

Trade names in this publication are used solely for the purpose of providing specific information. Such use herein is not a guarantee or warranty of the products named and does not signify that they are approved to the exclusion of others. Mention of a proprietary product does not constitute an endorsement by the University of Florida nor does it imply lack of efficacy of similar products not mentioned.

Accepted for publication 31 August 2011.

http://dx.doi.org/10.1094/PDIS-03-11-0183

(C) 2012 The American Phytopathological Society management strategies such as field rotation, avoidance of cull piles, and the use of copper-based bactericides are also heavily utilized (15). When using copper bactericides, mixing with an ethylene bisdithiocarbamate (EBDC) compound such as manzeb or mancozeb is necessary to suppress copper-resistant strains of Xanthomonas that are predominant in a number of tomato-growing regions such as Florida and North Carolina $(20,25,29)$. However, this combination can cause phytotoxicity and limit yields, and has limited efficacy when environmental conditions are conducive to disease development (30). Moreover, EBDC may be carcinogenic and, hence, faces further regulation on food crops in the future (11). In contrast, the use of famoxadone plus cymoxanil in combination with copper hydroxide or mancozeb has recently been demonstrated to reduce bacterial spot as effectively as the coppermancozeb standard (30). The antibiotics streptomycin and kasugamycin have been evaluated to control bacterial spot on tomato $(39,41)$. Since resistance to streptomycin was found as early as the 1960s, the antibiotic was no longer recommended for the management of bacterial spot in field production $(36,37)$. Kasugamycin, formulated as Kasumin $2 \mathrm{~L}$, is labeled for several bacterial diseases on several crops worldwide but registration for this product in the United States is pending. In Mexico, kasugamycin is used to control bacterial spot on tomato and pepper. However, development of resistance to kasugamiycin in Xanthomonas spp. is possible because kasugamycin and streptomycin have similar modes of action in interfering with protein synthesis (45). Host plant resistance has been a very useful strategy of plant disease control but host resistance against bacterial spot has not been durable, to date (18). Moreover, commercial cultivars resistant to $X$. euvesicatoria and $X$. perforans are not available, although host resistance has been identified $(30,33)$. The recent development of biological control agents such as bacteriophages and plant-growth-promoting rhizobacteria has shown promising results under field conditions 
$(14,22)$. However, inconsistency of the biocontrol agents has also been reported $(3,23)$. It has been suggested that a program using multiple products with various modes of action may provide a better control of bacterial spot $(14,22,23,30)$. Alternative tools need to be evaluated as components of disease management programs for bacterial spot of tomato.

Acibenzolar-S-methyl (ASM; Actigard or Bion; Syngenta Crop Protection, Inc., Greensboro, NC) is a plant activator that induces systemic acquired resistance (SAR) to confer protection against a broad spectrum of plant pathogens (38). SAR is accompanied by an increased level of salicylic acid (SA) both locally and systemically and by the coordinated upregulation of a specific set of genes encoding pathogenesis-related (PR) proteins, which are thought to contribute to disease resistance (7). The use of ASM has been demonstrated to be efficacious against a number of plant diseases such as bacterial wilt (28), powdery mildew (9), root knot nematode (21), and tomato spotted wilt (6). Likewise, field studies have shed light on the efficacy of ASM against bacterial spot on tomato $(19,22,23)$. However, the practical application of ASM in disease management has been questioned because induced resistance is a host response affected by many factors, including the abiotic environment, host genotype, and the extent to which certain plant defenses are already induced (43).

Previous studies have shown the efficacy of ASM for bacterial spot control when applied on a 7- to 14-day schedule $(19,22$,
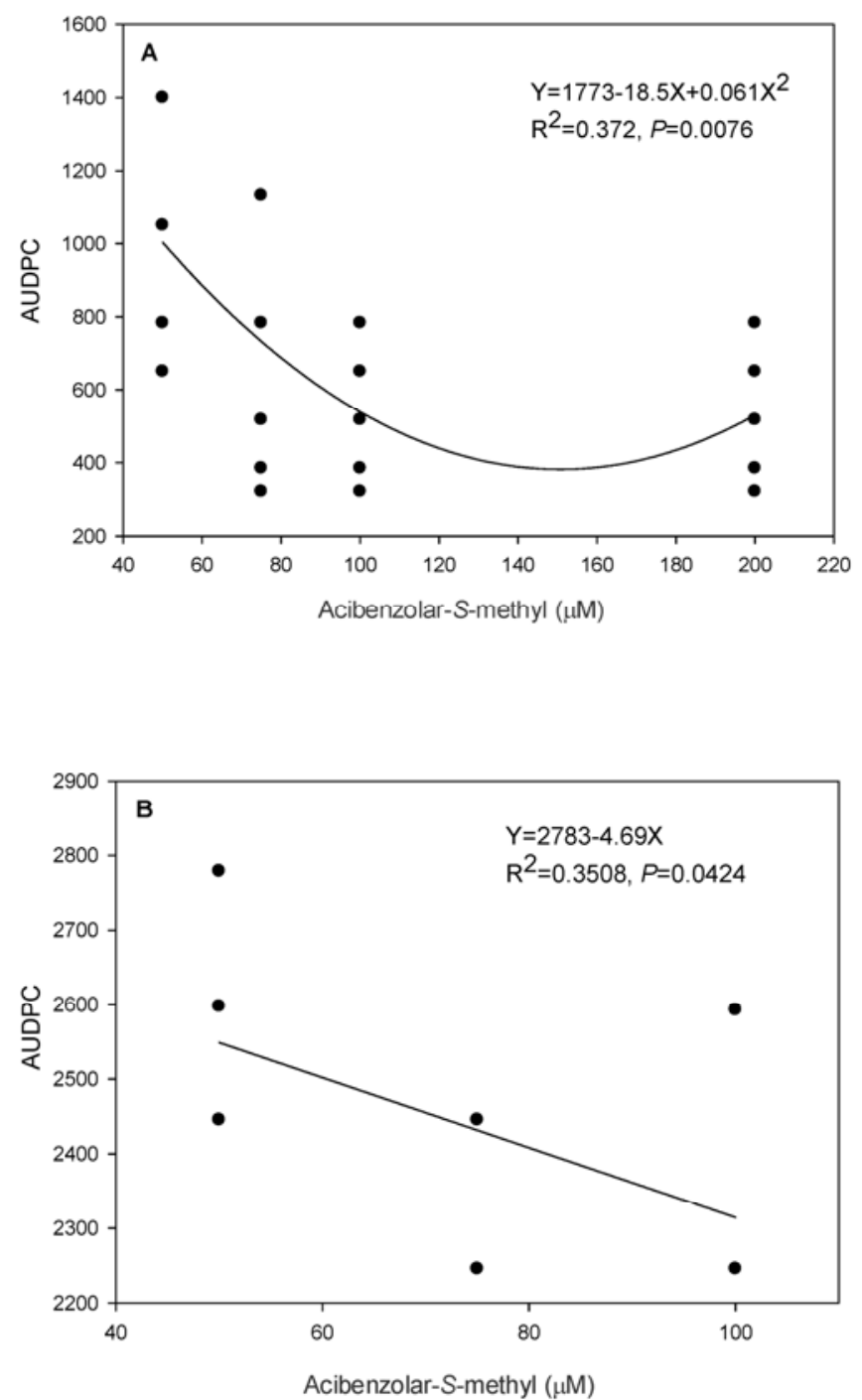

Fig. 1. Relationship between area under disease progress curve (AUDPC) and weekly application rates of acibenzolar-S-methyl in A, experiment 5 (fall 2009) and B, experiment 6 (spring 2010) at Wimauma, FL.
23,30). However, many growers are reluctant to adopt ASM due to concerns over reduced or delayed yields that have been documented in certain studies (19), and many have questioned whether the achieved control justifies the additional cost of ASM relative to copper-based bactericides. Although previous studies have examined high application rates of ASM, none have truly examined the impact of low rates and of application frequencies on the effective use of ASM in the management of bacterial spot. In order to determine whether a more efficient application strategy for ASM is possible, seven field experiments were conducted throughout the state of Florida to investigate the effects of the application frequency and rate on bacterial spot management. Here, we report that weekly applications of ASM at rates of 75 to $200 \mu \mathrm{M}$ or 1.58 to $4.20 \mathrm{~g}$ a.i. per 100 liters of spray water provided statistically equivalent control of bacterial spot on tomato without reducing tomato yields.

\section{Materials and Methods}

Inoculum preparation. Several strains of bacterial spot were used at different experimental locations in Florida. Experiments conducted at the North Florida Research and Education Center (NFREC) used X. perforans strain 91-118 (T3), those at the Plant Science Research and Education Unit (PSREU) and Live Oak used $X$. perforans strain XP621 (T4), and those at the Gulf Coast Research and Education Center (GCREC) used X. perforans strain T4 (T4). All strains used in this study were isolated from Florida tomato fields. Inoculum was prepared by growing bacterial strains on glucose-nutrient agar plates for 3 days at $28^{\circ} \mathrm{C}$. Then, the plates were flooded with $10 \mathrm{mM} \mathrm{MgSO}_{4}$ and adjusted to $10^{8} \mathrm{CFU} \mathrm{ml}{ }^{-1}$ for inoculations performed at NFREC, PSREU, and Live Oak and to $10^{6} \mathrm{CFU} \mathrm{m}{ }^{-1}$ for inoculations at GCREC. In order to enhance foliar infection, Silwet L-77 (Helena Chemical Co., Collierville, $\mathrm{TN})$ was added to the inoculum to a final concentration of $0.025 \%$ (vol/vol). The experiment conducted at the Tropical Research and Education Center (TREC) relied on natural inoculum for disease development.

Effects of biweekly ASM rates on bacterial spot, 2007 to 2008. Four field experiments were conducted from 2007 to 2008 to evaluate the effect of application rates of ASM on bacterial spot. Experiment 1 was conducted at the NFREC in spring 2007; experiments 2 and 3 were at the PSREU in spring and fall 2007; and experiment 4 was at Live Oak, FL, in fall 2008. Tomato 'Bella Rosa' was used in these four field trials. Guidelines established by the University of Florida/IFAS were followed for land preparation, fertilization, irrigation, weed management, and insect control (24). ASM treatments were applied biweekly (once every 2 weeks for all experiments described below) at $12.9,64.5$, and $129 \mu \mathrm{M}$, corresponding to $1 / 10,1 / 2$, and $1 \times$ of the labeled rate. In total, five applications were made per season in each trial. A standard copper program and a nontreated control were included in each field experiment. The copper program consisted of copper hydroxide $(815$ $\mathrm{g}$ a.i./ha; Kocide 3000) plus an EBDC fungicide (621 g a.i./ha; Manzate), which was applied weekly. Field applications of these treatments were made with a $\mathrm{CO}_{2}$-powered backpack sprayer adjusted to deliver 559 to 839 liters/ha at $275 \mathrm{kPa}$ depending on plant size. The five treatments were arranged in a randomized complete block design with four replicates for each treatment. Each plot consisted of two or three rows, in which each row was $8 \mathrm{~m}$ long with 15 plants at $50-\mathrm{cm}$ spacing at the NFREC and $5 \mathrm{~m}$ long with 10 plants at $46-\mathrm{cm}$ spacing at the other locations.

Effects of application frequency and rate, 2009 to 2010 . Because biweekly applications of ASM did not significantly reduce disease severity and disease epidemics in experiments 1 to 4 , weekly applications of ASM were included in experiments 5 to 7 . Experiments 5 and 6 were carried out at the GCREC in fall 2009 and spring 2010, respectively. Experiment 7 was conducted at the TREC in spring 2010. Four concentrations of 50, 75, 100, and 200 $\mu \mathrm{M}$ ASM were used in experiment 5 , which were applied weekly or biweekly. These four ASM concentrations were maintained throughout the season with increasing spray volumes (559 to 1,121 
liters/ha) based on plant size. Copper sulfate $(2,396 \mathrm{~g}$ a. i. /ha; Cuprofix Ultra 40D) plus an EBDC fungicide (1,688 $\mathrm{g}$ a.i./ha, Penncozeb 75 DF) were used as the standard program, and a control consisting of water alone was also included. The treatments of experiment 6 were the same as experiment 5 except the treatment of $200 \mu \mathrm{M}$ was excluded due to its adverse effects on disease control (Figs. 1A and 2) and delaying the reproductive stage of tomato plants (data not shown). 'SecuriTY 28' tomato was used in experiment 5 and 'XP 200' was used in experiment 6. The treatments were arranged in a randomized complete block design with six (experiment 5) or four (experiment 6) replicates for each treatment. Each plot was $6.4 \mathrm{~m}$ long with 14 plants at $46-\mathrm{cm}$ spacing. Spray methods as described above were followed.

Experiment 7 was conducted at the TREC in spring 2010. ASM treatments were applied weekly or biweekly at four concentrations of $30.3,44.6,60.6$, and $120 \mu \mathrm{M}$, for which the sprayed volume was adjusted to 559 to 935 liters/ha based on plant size. Copper hydroxide (516 g a.i./ha; Kocide 3000) plus an EBDC fungicide (621 g a.i./ha; Manzate) were used as the standard program, and a control consisting of water alone was also included. Tomato 'BHN 602' was used in this field trial. In total, six applications of these treatments were made with a $\mathrm{CO}_{2}$ backpack sprayer calibrated to deliver 559 to 935 liters/ha at $275 \mathrm{kPa}$. The treatments were arranged in a randomized complete block design with six replicates for each treatment. Each plot was $6.7 \mathrm{~m}$ long with 13 plants at 50$\mathrm{cm}$ spacing. The trial was terminated prematurely, and yield data were not collected, due to a sudden outbreak of late blight.

Disease and yield assessments. Plots were monitored weekly, and 5 or 10 plants within a plot were rated using the Horsfall-Bar-



Fig. 2. Relationship between disease severity and weekly application rates of acibenzolar-S-methyl in experiment 5 (fall 2009) at Wimauma, FL. ratt scale (13) to evaluate the percentage of canopy affected by bacterial spot. Values were converted to mid-percentages prior to statistical analysis. The area under disease progress curve (AUDPC) was calculated as previously described (35). Fruit were harvested and graded based on United States Department of Agriculture standards for experiments 5 and 6 at the GCREC. Weights of diseased, cull, marketable, and unmarketable fruit were recorded.

Statistical analysis. Generalized linear models employed in PROC GLIMMIX of SAS (version 9.2; SAS Institute, Gary, NC) were used to determine the effect of treatments on response variables. The effect of blocks was considered random and that of applied treatments was defined as fixed. Appropriate distribution models were chosen based on the type of data collected. The $t$ test was used to compare treatment means, and the CONTRAST procedure was used to determine the statistical importance of certain comparisons among the applied treatments. Regression analysis was performed to determine the relationship between ASM rate and response variables using SIGMAPLOT (version 10.0; Systat Software, Chicago).

\section{Results}

Effects of ASM rates on bacterial spot, 2007 to 2008. Compared with the untreated control and copper-EBDC standard, applications of ASM at 12.9, 64.5, and $129 \mu \mathrm{M}$ every 2 weeks did not cause a significant reduction in the final disease severity in experiments 1 to 3 (Table 1). In experiment 4, the final disease severity of the ASM treatment at $129 \mu \mathrm{M}$ was significantly lower than that of the untreated control by $50.8 \%$, whereas no significant difference was detected between ASM treatments and the copper-EBDC standard (Table 1). Applications of ASM every 2 weeks did not significantly reduce disease epidemics compared with the copper-EBDC standard or untreated control in experiments 1 to 4 (Table 1).

Effects of application frequency and rate, 2009 to 2010. In experiment 5 conducted at the GCREC, weekly applications of ASM resulted in a significant reduction of the final disease severity by $41.8 \%$ and of AUDPC by $32.2 \%$ compared with biweekly applications (Table 2). Contrast analysis suggested no significant difference between weekly applications of ASM and the copper-EBDC standard in disease control. However, weekly applications of ASM provided significantly greater control of bacterial spot than the untreated control, with an average of $71.5 \%$ reduction in the final disease severity and an average of $64.7 \%$ reduction in AUDPC. Although biweekly applications of ASM significantly reduced the final disease severity and AUDPC compared with the untreated control, the level of control was significantly less than the copperEBDC standard (Table 2). Symptoms of target spot, caused by the fungus Corynespora cassiicola, were observed on diseased fruit. However, foliar target spot symptoms were not sufficiently developed at the time of rating to distinguish them from symptoms of bacterial spot; therefore, foliar disease ratings included both diseases. Regression analysis suggested that quadratic models best

Table 1. Efficacy of biweekly applications (once every 2 weeks) of acibenzolar-S-methyl (ASM) compared with controls and standard bactericides to manage bacterial spot on tomatow

\begin{tabular}{|c|c|c|c|c|c|c|c|c|}
\hline \multirow[b]{2}{*}{ Treatment, rate } & \multicolumn{4}{|c|}{$Y_{f}(\%)^{x}$} & \multicolumn{4}{|c|}{ AUDPC $^{\mathbf{y}}$} \\
\hline & Exp. 1 & Exp. 2 & Exp. 3 & Exp. 4 & Exp. 1 & Exp. 2 & Exp. 3 & Exp. 4 \\
\hline $\operatorname{ASM}(12.9 \mu \mathrm{M})$ & 22.3 & 24.8 & 26.1 & $40.2 \mathrm{ab}$ & 359 & 342 & 680 & 748 \\
\hline $\operatorname{ASM}(64.5 \mu \mathrm{M})$ & 25.7 & 15.2 & 29.1 & $41.0 \mathrm{ab}$ & 417 & 246 & 828 & 791 \\
\hline $\operatorname{ASM}(129 \mu \mathrm{M})$ & 25.2 & 19.8 & 25.5 & $27.9 \mathrm{c}$ & 415 & 271 & 777 & 680 \\
\hline Standard ${ }^{\mathrm{z}}$ & 14.7 & 16.7 & 31.9 & $31.5 \mathrm{bc}$ & 238 & 282 & 726 & 581 \\
\hline Control & 27.1 & 21.2 & 27.5 & $45.3 \mathrm{a}$ & 472 & 307 & 778 & 875 \\
\hline$P>F$ & 0.4693 & 0.5830 & 0.2922 & 0.0138 & 0.3036 & 0.7843 & 0.6977 & 0.3247 \\
\hline
\end{tabular}

${ }^{\text {w }}$ Values followed by a different letter are significantly different $(P=0.05)$.

${ }^{\mathrm{x}} Y_{f}=$ final disease severity assessed as the percentage of canopy affected. The Horsfall-Barratt scale was used for all ratings but values were converted to mid-percentages prior to statistical analyses.

${ }^{y}$ Area under the disease progress curve (AUDPC) values were calculated using the formula $\Sigma\left[\left(\left[x_{\mathrm{i}}+x_{\mathrm{i}-1}\right] / 2\right)\left(t_{\mathrm{i}}-t_{\mathrm{i}-1}\right)\right]$, where $x_{\mathrm{i}}$ is the rating at each evaluation time and $\left(t_{\mathrm{i}}-t_{\mathrm{i}-1}\right)$ is the time between evaluations.

${ }^{\mathrm{z}}$ Standard $=$ Kocide $3000(1.96 \mathrm{~kg} / \mathrm{ha})+$ Manzate $(1.68 \mathrm{~kg} / \mathrm{ha})$. 
described the relationship between weekly applications of ASM rates and AUDPC (Fig. 1A) or the final disease severity (Fig. 2).

The application frequency and rate of ASM did not significantly affect the total fruit weight when compared with the untreated control and copper-EBDC standard (Table 2). However, the copperEBDC standard resulted in the highest marketable yield due to significantly lower levels of diseased fruit and cull percentages, probably due to the effectiveness of the EBDC against target spot. Weekly applications of ASM increased marketable yields by $16.1 \%$ compared with biweekly ASM applications $(P=0.0633$; Table 2). Of these weekly ASM treatments, the total fruit weight and marketable yield of the first harvest were significantly lower on plants treated with $200 \mu \mathrm{M}$ ASM than those with 75 or $100 \mu \mathrm{M}$ (data not shown). However, the total yield of these weekly ASM treatments was not significantly different when two harvest data sets were combined. Total tomato yields averaged across weekly ASM treatments were $20 \%$ greater $(P=0.0865)$ than the control, whereas biweekly ASM treatments were only $10 \%$ greater $(P=0.3669)$ on average. No significant difference was detected in the percentage of diseased fruit between weekly and biweekly applications of ASM but biweekly applications of ASM significantly increased the cull percentage by $17.2 \%(P=0.0449$; Table 2$)$.

Applications of ASM at $200 \mu \mathrm{M}$ in experiment 5 probably delayed the reproductive stage of tomato plants based on yield data (data not shown). Therefore, the treatment of $200 \mu \mathrm{M}$ ASM was not included in experiment 6 . As with experiment 5 , experiment 6 showed that weekly applications of ASM significantly performed better than biweekly applications in reducing the final disease severity $(P=0.0019$; Table 3$)$. However, no significant difference was detected between weekly applications of ASM and the copperEBDC standard or untreated control. In contrast to experiment 5, experiment 6 showed that both weekly and biweekly applications of ASM significantly reduced AUDPC when compared with copper-EBDC (10.2 and $6.54 \%$, respectively) or the untreated control (14.2 and $10.3 \%$, respectively). Again, weekly applications performed significantly better than the biweekly applications in reducing disease development $(P=0.0201$; Table 3$)$. Of the weekly application treatments, spraying $100 \mu \mathrm{M}$ resulted in a lower AUDPC. A linear model was observed to significantly describe only the relationship between ASM concentrations and AUDPC (Fig. 1B) but not the other response variables.

No significant difference was detected in the total weight and marketable fruit yield between treatments in experiment 6. ASM significantly reduced diseased fruit compared with copper-EBDC or the untreated control but no significant difference was detected between weekly and biweekly applications of ASM (Table 3). Overall, neither weekly nor biweekly applications of ASM significantly reduced the cull percentage of fruit when compared with copper-EBDC and the untreated control. Moreover, no significant difference was observed between weekly and biweekly applications in cull fruit (Table 3 ).

In experiment 7 conducted at the TREC, weekly applications of ASM significantly reduced the final disease severity by $14.1 \%$ compared with copper-EBDC. A marginally significant difference was detected between weekly applications of ASM and the untreated control $(P=0.0697$; Table 4$)$, although the former reduced the final disease severity by $10.1 \%$. Compared with biweekly applications of ASM, weekly applications of ASM significantly reduced AUDPC by $14.0 \%(P=0.0015$; Table 4$)$. Moreover, disease progress was significantly lower in the weekly ASM treatments than the copper-EBDC or control treatments. In contrast, biweekly ASM treatments did not perform significantly better than copper-EBDC and control treatments. Regression analysis suggested no significant relationship between ASM concentrations and the final disease severity or AUDPC in the TREC trial.

\section{Discussion}

In this study, we present data demonstrating that the field efficacy of ASM in reducing bacterial spot on tomato is associated with its application frequency and rate. Overall, our results consistently indicated that weekly applications of ASM significantly outperformed biweekly applications in reducing disease progress (experiments 5 to 7 ) and the final severity (experiments 5 and 6) of bacterial spot. Weekly ASM applications at rates as low as 75 to $200 \mu \mathrm{M}$ were statistically equivalent in managing bacterial spot of tomato without reducing tomato yields, although rates as low as $30.3 \mu \mathrm{M}$ were also effective. Optimizing the application frequency and rate of ASM may improve the overall effectiveness of ASM

Table 2. Effect of application rates and frequencies of acibenzolar-S-methyl (ASM) on bacterial spot and target spot on tomato ('SecuriTY28') in experiment 5 under field conditions (fall 2009 at Wimauma, FL)

\begin{tabular}{|c|c|c|c|c|c|c|}
\hline Treatment (rate), frequency ${ }^{t}$ & $Y_{f}(\%)^{\mathrm{u}}$ & $\mathbf{A U D P C}^{\mathbf{v}}$ & $\begin{array}{l}\text { Total weight } \\
\text { (ton/ha) }\end{array}$ & $\begin{array}{c}\text { Marketable } \\
\text { yield (ton/ha) }\end{array}$ & $\begin{array}{l}\text { Diseased fruit } \\
(\%)^{\mathrm{w}}\end{array}$ & $\operatorname{Cull}(\%)^{\mathrm{x}}$ \\
\hline ASM $(50 \mu \mathrm{M})$, weekly & $26.4 \mathrm{c}$ & $1,012 \mathrm{c}$ & 55.9 & $22.8 \mathrm{bc}$ & $2.84 \mathrm{ab}$ & $35.7 \mathrm{ab}$ \\
\hline ASM $(75 \mu \mathrm{M})$, weekly & $14.6 \mathrm{de}$ & $713 \mathrm{de}$ & 47.5 & $25.2 \mathrm{~b}$ & $4.26 \mathrm{a}$ & $25.7 \mathrm{~cd}$ \\
\hline ASM $(100 \mu \mathrm{M})$, weekly & $11.4 \mathrm{e}$ & $552 \mathrm{e}$ & 43.7 & $22.5 \mathrm{bc}$ & $6.41 \mathrm{a}$ & $25.9 \mathrm{bcd}$ \\
\hline ASM $(200 \mu \mathrm{M})$, weekly & $13.0 \mathrm{e}$ & $530 \mathrm{e}$ & 40.6 & $18.8 \mathrm{bc}$ & $5.62 \mathrm{a}$ & $28.7 \mathrm{abc}$ \\
\hline ASM $(50 \mu \mathrm{M})$, biweekly & $46.8 \mathrm{~b}$ & $1,400 \mathrm{~b}$ & 42.5 & $18.6 \mathrm{bc}$ & $5.09 \mathrm{a}$ & $33.5 \mathrm{abc}$ \\
\hline ASM $(75 \mu \mathrm{M})$, biweekly & $23.3 \mathrm{~cd}$ & $909 \mathrm{~cd}$ & 41.7 & $20.2 \mathrm{bc}$ & $4.39 \mathrm{a}$ & $30.1 \mathrm{abc}$ \\
\hline ASM $(100 \mu \mathrm{M})$, biweekly & $29.6 \mathrm{c}$ & $998 \mathrm{c}$ & 43.8 & $18.1 \mathrm{c}$ & $5.63 \mathrm{a}$ & $37.2 \mathrm{a}$ \\
\hline ASM $(200 \mu \mathrm{M})$, biweekly & 20.9 cde & $832 \mathrm{~cd}$ & 44.6 & $19.4 \mathrm{bc}$ & $5.41 \mathrm{a}$ & $35.2 \mathrm{abc}$ \\
\hline Standard, weeklyy & $11.4 \mathrm{e}$ & $713 \mathrm{de}$ & 47.9 & $31.9 \mathrm{a}$ & $0.34 \mathrm{~b}$ & $19.7 \mathrm{~d}$ \\
\hline Control $^{\mathrm{z}}$ & $57.3 \mathrm{a}$ & $1,988 \mathrm{a}$ & 39.1 & $20.8 \mathrm{bc}$ & $3.08 \mathrm{a}$ & $26.1 \mathrm{bcd}$ \\
\hline Probability distribution of model & Normal & Normal & Normal & Normal & Binomial & Binomial \\
\hline$P>F$ & $<0.0001$ & $<0.0001$ & 0.2039 & 0.0054 & $<0.0001$ & 0.0088 \\
\hline \multicolumn{7}{|l|}{ Contrast $P>F$} \\
\hline ASM (weekly) vs. ASM (biweekly) & $<0.0001$ & $<0.0001$ & 0.1902 & 0.0633 & 0.5662 & 0.0449 \\
\hline ASM (weekly) vs. standard & 0.2083 & 0.9039 & 0.8353 & 0.0007 & 0.0132 & 0.0084 \\
\hline ASM (weekly) vs. control & $<0.0001$ & $<0.0001$ & 0.0865 & 0.5645 & 0.2732 & 0.4487 \\
\hline ASM (biweekly) vs. standard & $<0.0001$ & 0.0013 & 0.2992 & $<0.0001$ & 0.0098 & 0.0002 \\
\hline ASM (biweekly) vs. control & $<0.0001$ & $<0.0001$ & 0.3669 & 0.5359 & 0.1589 & 0.0443 \\
\hline
\end{tabular}

s Values followed by a different letter are significantly different $(P=0.05)$.

${ }^{\mathrm{t}}$ For application frequency, biweekly = once every 2 weeks.

" Final disease severity rated at 71 days after transplanting.

${ }^{\vee}$ Area under the disease progress curve (AUDPC) values were calculated using the formula $\Sigma\left[\left(\left[x_{\mathrm{i}}+x_{\mathrm{i}-1}\right] / 2\right)\left(t_{\mathrm{i}}-t_{\mathrm{i}-1}\right)\right]$, where $x_{\mathrm{i}}$ is the rating at each evaluation time and $\left(t_{\mathrm{i}}-t_{\mathrm{i}-1}\right)$ is the time between evaluations.

${ }^{\mathrm{w}}$ Diseased fruit $(\%)$ was evaluated based on weight; fruit exhibited symptoms typical of target spot caused by Corynespora cassiicola.

${ }^{\mathrm{x}}$ Cull (\%) represents the percentage of total fruit weight discarded due to physical defects.

${ }^{y}$ Standard $=$ Cuprofix $40 \mathrm{D}(3.37 \mathrm{~kg} / \mathrm{ha})+$ Penncozeb $75 \mathrm{DF}(2.25 \mathrm{~kg} / \mathrm{ha})$.

${ }^{\mathrm{z}}$ Control was sprayed with water only. 
when used alone or in combination with other strategies to manage bacterial spot of tomato, while also improving the economics and possibly minimizing the risk of yield reductions often observed in ASM trials and by growers.

The duration of induced resistance triggered by ASM affects disease progress due to the production of defense compounds in the plant. The period of time between the application of ASM and effective activation of induced resistance is rather short in tomato (3 to 7 days) $(1,2)$, because ASM rapidly translocates from treated to untreated tomato leaves $(2,32)$. The maximum translocation occurs at $8 \mathrm{~h}$ after application, and ASM reaches a negligible level at $72 \mathrm{~h}$ after treatment (32). Induced resistance in tomato plants is activated when ASM and its metabolites are completely degraded (32). The effectiveness of induced resistance by ASM significantly decreased 9 to 12 days after spraying ASM, which was associated with a similar decrease in total soluble phenolic compounds and other defense responses (4,5). Similarly, ASM-induced $P R-1$, a SAR marker, decreased to baseline levels by 7 days following the first ASM application. Reapplication of ASM led to the rapid expression of $P R-1$ within 1 to 2 days but the expression of the gene was considerably declined afterward (12). This gene expression pattern suggests that the application frequency of ASM is important for induced resistance. The substantial decrease in defense responses may partly explain why applying ASM every 2 weeks compromised disease control in our experiments. Although the expression pattern and magnitude of defense genes induced by ASM in tomato plants are likely cultivar dependent (12), experiments 5 to 7 used three different cultivars and all showed that weekly applications of ASM performed significantly better in reducing disease development of bacterial spot. To further investigate the effect of ASM application timing on disease control levels, changes in the levels of plant defense products such as PR proteins or expression of $P R$ genes would need to be monitored in order to determine the level that effectively inhibits bacterial infection and viability.

This study also shows that the efficacy of ASM in eliciting resistance to bacterial spot depends on the rate of the product applied, which in turn determines the amount of the elicitor absorbed by tomato plants. Our results showed that the final severity and disease progress of bacterial spot were considerably reduced with increasing ASM rates (Figs. 1 and 2). This increase in control of bacterial spot induced by ASM may result from an increase in plant defense products and stress alleviation (4). Apart from the rate of ASM applied, adsorption of ASM may be influenced by other factors, such as plant age and health, application methods, and the environmental conditions under which the field experiments are performed. For example, bacterial spot of tomato may occur as early as transplant production in the greenhouse (44). Early application of ASM on tomato seedlings may act as a protective agent against bacterial spot along with other diseases. Although weekly applications of ASM at 75 to $200 \mu \mathrm{M}$ provided statistically equivalent control of bacterial spot on field-grown

Table 4. Effects of application rates and frequencies of acibenzolar- $S$ methyl (ASM) on bacterial spot on tomato ('BHN 602') in experiment 7 under field conditions (spring 2010 at Homestead, FL) ${ }^{\mathrm{u}}$

\begin{tabular}{lll}
\hline Treatment (rate), frequency $^{\mathrm{v}}$ & $\boldsymbol{Y}_{\boldsymbol{f}}(\boldsymbol{\%})^{\mathrm{w}}$ & AUDPC$^{\mathbf{x}}$ \\
\hline ASM $(30.3 \mu \mathrm{M})$, weekly & $45.9 \mathrm{abc}$ & $502 \mathrm{~cd}$ \\
ASM $(44.6 \mu \mathrm{M})$, weekly & $43.3 \mathrm{bc}$ & $515 \mathrm{bcd}$ \\
ASM $(60.6 \mu \mathrm{M})$, weekly & $41.4 \mathrm{c}$ & $449 \mathrm{~d}$ \\
ASM $(120 \mu \mathrm{M})$, weekly & $46.7 \mathrm{abc}$ & $509 \mathrm{~cd}$ \\
ASM $(30.3 \mu \mathrm{M})$, biweekly & $47.5 \mathrm{abc}$ & $566 \mathrm{abc}$ \\
ASM $(44.6 \mu \mathrm{M})$, biweekly & $46.8 \mathrm{abc}$ & $551 \mathrm{abc}$ \\
ASM $(60.6 \mu \mathrm{M})$, biweekly & $46.5 \mathrm{abc}$ & $567 \mathrm{abc}$ \\
ASM $(120 \mu \mathrm{M})$, biweekly & $48.1 \mathrm{abc}$ & $569 \mathrm{abc}$ \\
Standard, weekly & $51.6 \mathrm{a}$ & $618 \mathrm{a}$ \\
Control & $49.3 \mathrm{ab}$ & $594 \mathrm{ab}$ \\
Probability distribution of model & Normal & Normal \\
$P>F$ & 0.0183 & 0.0074 \\
Contrast $P>F$ & & \\
ASM (weekly) vs. ASM (biweekly) & 0.0953 & 0.0015 \\
ASM (weekly) vs. bactericides & 0.0097 & 0.0004 \\
ASM (weekly) vs. control & 0.0697 & 0.0034 \\
ASM (biweekly) vs. bactericides & 0.1118 & 0.0982 \\
ASM (biweekly) vs. control & 0.4390 & 0.3472 \\
\hline
\end{tabular}

u Values followed by a different number are significantly different $(P=0.05)$.

${ }^{\mathrm{v}}$ For application frequency, biweekly = once every 2 weeks.

${ }^{\mathrm{w}}$ Final disease severity rated at 68 days after transplanting.

${ }^{x}$ Area under the disease progress curve (AUDPC) values were calculated using the formula $\Sigma\left[\left(\left[x_{\mathrm{i}}+x_{\mathrm{i}-1}\right] / 2\right)\left(t_{\mathrm{i}}-t_{\mathrm{i}-1}\right)\right]$, where $x_{\mathrm{i}}$ is the rating at each evaluation time and $\left(t_{\mathrm{i}}-t_{\mathrm{i}-1}\right)$ is the time between evaluations.

${ }^{\text {y }}$ Standard $=$ Kocide $3000(1.12 \mathrm{~kg} / \mathrm{ha})+$ Manzate $(1.68 \mathrm{~kg} / \mathrm{ha})$.

${ }^{\mathrm{z}}$ Control was sprayed with water only.

Table 3. Effects of application rates and frequencies of acibenzolar- $S$-methyl (ASM) on bacterial spot on tomato ('XP 200') in experiment 6 under field conditions (spring 2010 at Wimauma, FL) ${ }^{\mathrm{s}}$

\begin{tabular}{|c|c|c|c|c|c|c|}
\hline Treatment (rate), frequency ${ }^{t}$ & $Y_{f}(\%)^{\mathrm{u}}$ & $\operatorname{AUDPC}^{\mathbf{v}}$ & $\begin{array}{c}\text { Total weight } \\
\text { (ton/ha) }\end{array}$ & $\begin{array}{c}\text { Marketable } \\
\text { yield (ton/ha) }\end{array}$ & $\begin{array}{c}\text { Diseased fruit } \\
(\%)^{\mathrm{w}}\end{array}$ & Cull $(\%)^{x}$ \\
\hline ASM $(50 \mu \mathrm{M})$, weekly & 92.1 & $2,567 \mathrm{bcd}$ & 24.0 & 21.0 & 1.95 & 11.9 \\
\hline ASM $(75 \mu \mathrm{M})$, weekly & 91.0 & $2,396 \mathrm{ef}$ & 26.8 & 23.2 & 1.86 & 6.99 \\
\hline ASM $(100 \mu \mathrm{M})$, weekly & 91.0 & $2,333 \mathrm{f}$ & 27.2 & 24.5 & 1.18 & 6.29 \\
\hline ASM $(50 \mu \mathrm{M})$, biweekly & 93.2 & 2,554 cde & 24.0 & 22.4 & 2.45 & 2.87 \\
\hline ASM $(75 \mu \mathrm{M})$, biweekly & 94.4 & $2,656 \mathrm{bc}$ & 23.9 & 21.8 & 2.03 & 6.54 \\
\hline ASM $(100 \mu \mathrm{M})$, biweekly & 94.4 & $2,421 \mathrm{def}$ & 22.6 & 21.2 & 0.19 & 8.85 \\
\hline Standard, weekly y & 93.3 & $2,721 \mathrm{ab}$ & 23.7 & 21.8 & 3.41 & 5.76 \\
\hline Control $^{z}$ & 93.3 & $2,835 \mathrm{a}$ & 26.3 & 23.9 & 3.35 & 6.24 \\
\hline Probability distribution of model & Normal & Normal & Normal & Normal & Binomial & Binomial \\
\hline$P>F$ & 0.0796 & $<0.0001$ & 0.7496 & 0.8636 & 0.1059 & 0.0929 \\
\hline \multicolumn{7}{|l|}{ Contrast $P>F$} \\
\hline ASM (weekly) vs. ASM (biweekly) & 0.0019 & 0.0201 & 0.2134 & 0.5239 & 0.2691 & 0.1015 \\
\hline ASM (weekly) vs. standard & 0.0876 & 0.0002 & 0.3717 & 0.6144 & 0.0318 & 0.2849 \\
\hline ASM (weekly) vs. control & 0.0876 & $<0.0001$ & 0.9118 & 0.6738 & 0.0366 & 0.3964 \\
\hline ASM (biweekly) vs. standard & 0.4814 & 0.0105 & 0.9212 & 0.9992 & 0.0120 & 0.9063 \\
\hline ASM (biweekly) vs. control & 0.4814 & 0.0001 & 0.2907 & 0.3775 & 0.0134 & 0.7135 \\
\hline
\end{tabular}

s Values followed by a different letter are significantly different $(P=0.05)$.

${ }^{\mathrm{t}}$ For application frequency, biweekly $=$ once every 2 weeks.

"Area under the disease progress curve (AUDPC) values were calculated using the formula $\Sigma\left[\left(\left[x_{\mathrm{i}}+x_{\mathrm{i}-1}\right] / 2\right)\left(t_{\mathrm{i}}-t_{\mathrm{i}-1}\right)\right]$, where $x_{\mathrm{i}}$ is the rating at each evaluation time and $\left(t_{\mathrm{i}}-t_{\mathrm{i}-1}\right)$ is the time between evaluations.

${ }^{\mathrm{v}}$ Final disease severity rated at 62 days after transplanting.

${ }^{\mathrm{w}}$ Diseased fruit (\%) was evaluated based on weight.

${ }^{\mathrm{x}}$ Cull (\%) represents the percentage of total fruit weight discarded due to physical defects.

${ }^{\mathrm{y}}$ Standard $=$ Cuprofix 40D $(3.37 \mathrm{~kg} / \mathrm{ha})+$ Penncozeb $75 \mathrm{DF}(2.25 \mathrm{~kg} / \mathrm{ha})$.

${ }^{\mathrm{z}}$ Control was sprayed with water only. 
tomato plants, it has not been evaluated whether the concentration range provides the same efficacy on seedlings.

The physiological cost of induced resistance by ASM has been previously discussed in terms of a tradeoff between effective disease control and phytotoxicity or reduced yield $(40,42)$. Although the physiological cost of induced resistance by ASM may occur, it may be possible to overcome by modifying agricultural practices such as fertilization and irrigation. In contrast, the cost would be exacerbated under stresses. However, this tradeoff seems to vary depending on plant species and environmental conditions (42). A single application of ASM at $30 \mathrm{~g} / \mathrm{ha}$ on wheat plants induced resistance against powdery mildew in the field throughout the growing season. This long-lasting protection in ASM-treated wheat plants did not result in decreased yield compared with standard fungicides (9). Conversely, the negative effect of ASM on the yield of pepper has been observed and, thus, the copper-mancozeb standard has been considered an appropriate spray program for control of bacterial spot on pepper (31). A statistically nonsignificant but numerically consistent yield reduction has been previously reported in tomato plants treated with ASM compared with those treated with the standard fungicide program (19). In experiment 6 , artificially inoculated with $X$. perforans, the total fruit weight and marketable yield of the first harvest were significantly lower on plants treated weekly with $200 \mu \mathrm{M}$ ASM than those with 75 or 100 $\mu \mathrm{M}$ (data not shown). However, when two harvest data sets of the same season were combined, no significant difference was detected among these weekly ASM treatments. This finding suggests that higher rates of ASM may delay the reproductive development of tomato plants. ASM treatments as a group had yields statistically similar to both the copper-EBDC standard and the untreated control. Experiment 5 conducted in the fall of 2009 showed that the marketable yield of ASM treatments was significantly lower than that of the copper-EBDC standard. This yield reduction was mostly due to the impact of target spot which was also present in the trial and accounted for the unusually high numbers of diseased and culled fruit. The protectant copper-EBDC mixture was far more effective for protecting fruit from target spot. In contrast, diseased fruit of copper-EBDC-treated plants were significantly higher than those of ASM-treated plants in experiment 6 performed in spring 2010. It is not clear whether this difference in the fruit infection is associated with effects of ASM under various disease pressures resulting from environmental factors. It may be necessary to further investigate whether ASM or SAR in general affects fruit development and tomato fruit diseases. In addition, allocation costs may need to be quantified to determine the discrepancy between plant growth and plant defense in the absence of pathogen challenge (42). In the absence of bacterial spot, a reduction in flower buds and open flowers and delay in fruit maturity was observed on ASM-treated pepper plants, resulting in lower yield (31). The allocation cost has not been well evaluated on ASM-treated tomato plants under field conditions.

Although the copper-EDBC standard is generally as effective as ASM in control of bacterial spot, ASM may perform better than the standard when copper-resistant strains are predominant in natural epidemics. It has been observed that weekly applications of copper aggravated disease severity of bacterial spot on tomato in the field where copper-resistant strains are predominant (19). A survey in 2006 found that all 377 Xanthomonas strains collected from 20 tomato fields throughout Florida were resistant to copper (J. B. Jones, unpublished data). In experiment 7 conducted at TREC, naturally occurring $X$. perforans was used as the source of inoculum and copper-resistant strains were present (25). Weekly applications of ASM provided significantly better control of tomato bacterial spot than the copper-EDBC standard. This finding suggests that ASM is an effective tool to manage copper-resistant strains in the field. Moreover, when disease pressure of bacterial spot is high, ASM may be more reliable than copper-EDBC, as observed in experiment 6 conducted in spring 2010 at the GCREC, which was initially inoculated with a copper-resistant strain of $X$. perforans. Both weekly and biweekly applications of ASM significantly re- duced disease progress compared with copper-EBDC, suggesting that ASM is effective under high disease pressure of bacterial spot in the field.

Taken together, weekly ASM applications at rates as low as 75 to $200 \mu \mathrm{M}$ were statistically equivalent in managing bacterial spot of tomato. Because these trials used susceptible cultivars, it is not clear whether the appropriate application rate and frequency of ASM indicated by this study can provide an additive protection on moderately resistant and resistant cultivars against bacterial spot. SAR induced by ASM is considered a broad-spectrum defense, suggesting that induced resistance against bacterial spot is generally effective to all races and copper-resistant strains (19). Additional benefits of controlling other pests of tomato could also derive from ASM treatments (22). As a result, the efficacy of the ASM application frequency and rate may need to be further evaluated for other important pathogens in tomato production, making ASM a practical and efficient tool for plant disease management. Knowledge of ASM uptake by roots and its metabolism in plants is scarce but soil application of ASM has been demonstrated to be efficacious against citrus canker (10). An effort to investigate soil application of ASM at various rates and frequencies for control of bacterial spot on tomato is underway.

\section{Acknowledgments}

This research was supported in part by a grant from the United States Department of Agriculture SARE (Momol, Jones, Ji, Olson, 2006-2009) and NIFA special grant 2006-34103-16929 to J. B. Jones and M. T. Momol. We thank B. C. Hughes, C. M. Dyer, R. C. Willis, H. M. Adkison, and T. L. White for their technical assistance.

\section{Literature Cited}

1. Baysal, Ö., Soylu, E. M., and Soylu, S. 2003. Induction of defence-related enzymes and resistance by the plant activator acibenzolar-S-methyl in tomato seedlings against bacterial canker caused by Clavibacter michiganensis ssp. michiganensis. Plant Pathol. 52:747-753.

2. Benhamou, N., and Belanger, R. R. 1998. Benzothiadiazole-mediated induced resistance to Fusarium oxysporum f. sp. radicis-lycopersici in tomato. Plant Physiol. 118:1203-1212.

3. Briceno-Montero, G., and Miller, S. A. 2005. Evaluation of biological control options for bacterial spot management during tomato transplant production. Acta Hortic. 695:357-363.

4. Cavalcanti, F. R., Resende, M. L. V., Lima, J., Silveira, J. A. G., and Oliveira, J. T. A. 2006. Activities of antioxidant enzymes and photosynthetic responses in tomato pre-treated by plant activators and inoculated by Xanthomonas vesicatoria. Physiol. Mol. Plant Pathol. 68:198-208.

5. Cavalcanti, F. R., Resende, M. L. V., Zacaroni, A. B., Ribeiro Júnior, P. M., Costa, J. C. B., and Souza, R. M. 2006. Acibenzolar-S-methyl and Ecolife in the induction of defense responses in tomato against bacterial spot (Xanthomonas vesicatoria). Fitopatol. Brasil. 31:372-380.

6. Csinos, A. S., Pappu, H. R., McPherson, R. M., and Stephenson, M. G. 2001. Management of Tomato spotted wilt virus in flue-cured tobacco with acibenzolar-S-methyl and imidacloprid. Plant Dis. 85:292-296.

7. Durrant, W. E., and Dong, X. 2004. Systemic acquired resistance. Annu. Rev. Phytopathol. 42:185-209.

8. Gardner, M. G., and Kendrick, J. B. 1923. Bacterial spot of tomato and pepper. Phytopathology 13:307-315.

9. Görlach, J., Volrath, S., Knauf-Beiter, G., Hengy, G., Beckhove, U., Kogel, K.-H., Oostendorp, M., Staub, T., Ward, E., Kessmann, H., and Ryals, J. 1996. Benzothiadiazole, a novel class of inducers of systemic acquired resistance, activates gene expression and disease resistance in wheat. Plant Cell 8:629-643

10. Graham, J. H., and Myers, M. E. Soil application of imidacloprid, thiamethoxam and acibenzolar-S-methyl for induction of SAR to control citrus canker in young grapefruit trees. Plant Dis. In press.

11. Gullino, M. L., Tinivella, F., Garibaldi, A., Kemmitt, G. M., Bacci, L., and Sheppard, B. 2010. Mancozeb: past, present, and future. Plant Dis. 94:10761087.

12. Herman, M. A. B., Restrepo, S., and Smart, C. D. 2007. Defense gene expression patterns of three SAR-induced tomato cultivars in the field. Physiol. Mol. Plant Pathol. 71:192-200.

13. Horsfall, J. G., and Barratt, R. W. 1945. An improved grading system for measuring plant diseases. (Abstr.) Phytopathology 35:655.

14. Ji, P., Campbell, H. L., Kloepper, J. W., Jones, J. B., Suslow, T. V., and Wilson, M. 2006. Integrated biological control of bacterial speck and spot of tomato under field conditions using foliar biological control agents and plant growth-promoting rhizobacteria. Biol. Control 36:358-367.

15. Jones, J. B., Jones, J. P., Stall, J. P., and Zitter, T. A. 1991. Compendium of Tomato Diseases. American Phytopathological Society, St. Paul, MN.

16. Jones, J. B., Lacy, G. H., Bouzar, H., Stall, R. E., and Schaad, N. W. 2004. 
Reclassification of the xanthomonads associated with bacterial spot disease of tomato and pepper. Syst. Appl. Microbiol. 27:755-762.

17. Jones, J. B., Momol, M. T., Obradovic, A., Balogh, B., and Olson, S. M. 2005. Bacterial spot management on tomatoes. Acta Hortic. 695:119-124.

18. Jones, J. B., Stall, R. E., and Bouzar, H. 1998. Diversity among xanthomonads pathogenic on pepper and tomato. Annu. Rev. Phytopathol. 36:41-58.

19. Louws, F. J., Wilson, M., Campbell, H. L., Cuppels, D. A., Jones, J. B., Shoemaker, P. B., Sahin, F., and Miller, S. A. 2001. Field control of bacterial spot and bacterial speck of tomato using a plant activator. Plant Dis. 85:481-488.

20. Marco, G. M., and Stall, R. E. 1983. Control of bacterial spot of pepper initiated by strains of Xanthomonas campestris pv. vesicatoria that differ in sensitivity to copper. Plant Dis. 67:779-781.

21. Molinari, S., and Baser, N. 2010. Induction of resistance to root-knot nematodes by SAR elicitors in tomato. Crop Prot. 29:1354-1362.

22. Obradovic, A., Jones, J. B., Momol, M. T., Balogh, B., and Olson, S. M. 2004. Management of tomato bacterial spot in the field by foliar applications of bacteriophages and SAR inducers. Plant Dis. 88:736-740.

23. Obradovic, A., Jones, J. B., Momol, M. T., Olson, S. M., Jackson, L. E., Balogh, B., Guven, K., and Iriarte, F. B. 2005. Integration of biological control agents and systemic acquired resistance inducers against bacterial spot on tomato. Plant Dis. 89:712-716.

24. Olson, S. M., and Santos, B. S. 2010. Vegetable Production Handbook for Florida 2010-2011. Florida Cooperative Service, University of Florida.

25. Pernezny, K., Nagata, R., Havranek, N., and Sanchez, J. 2008. Comparison of two culture media for determination of the copper resistance of Xanthomonas strains and their usefulness for prediction of control with copper bactericides. Crop Prot. 27:256-262.

26. Pohronezny, K., and Volin, R. B. 1983. The effect of bacterial spot on yield and quality of fresh market tomatoes. HortScience 18:69-70.

27. Pohronezny, K., Waddill, V. H., Schuster, D. J., and Sonoda, R. M. 1986. Integrated pest management for Florida tomatoes. Plant Dis. 70:96-102.

28. Pradhanang, P. M., Ji, P., Momol, M. T., Olson, S. M., Mayfield, J. L., and Jones, J. B. 2005. Application of acibenzolar-S-methyl enhances host resistance in tomato against Ralstonia solanacearum. Plant Dis. 89:989-993.

29. Ritchie, D. F., and Dittapongpitch, V. 1991. Copper- and streptomycinresistant strains and host differentiated races of Xanthomonas campestris pv. vesicatoria in North Carolina. Plant Dis. 75:733-736.

30. Roberts, P. D., Momol, M. T., Ritchie, L., Olson, S. M., Jones, J. B., and Balogh, B. 2008. Evaluation of spray programs containing famoxadone plus cymoxanil, acibenzolar-S-methyl, and Bacillus subtilis compared to copper sprays for management of bacterial spot on tomato. Crop Prot. 27:15191526.

31. Romero, A. M., Kousik, C. S., and Ritchie, D. F. 2001. Resistance to bacterial spot in bell pepper induced by acibenzolar-S-methyl. Plant Dis. 85:189-194.

32. Scarponi, L., Buonaurio, R., and Martinetti, L. 2001. Persistence and translocation of a benzothiadiazole derivative in tomato plants in relation to systemic acquired resistance against Pseudomonas syringae pv. tomato. Pest Manage. Sci. 57:262-268.

33. Scott, J. W., and Jones, J. B. 1986. Sources of resistance to bacterial spot in tomato. HortScience 21:304-306.

34. Scott, J. W., Somodi, G. C., and Jones, J. B. 1989. Resistance to bacterial spot fruit infection in tomato. HortScience 24:825-827.

35. Shaner, G., and Finney, R. E. 1977. The effect of nitrogen fertilizer on the expression of slow mildewing resistance in Knox wheat. Phytopathology 67:1051-1056.

36. Stall, R. E., Jones, J. B., and Minsavage, G. V. 2009. Durability of resistance in tomato and pepper to xanthomonads causing bacterial spot. Annu. Rev. Phytopathol. 47:265-284.

37. Stall, B. E., and Thayer, P. L. 1962. Streptomycin resistance of the bacterial spot pathogen and control with streptomycin. Plant Dis. Rep. 46:389-392.

38. Tally, A., Oostendorp, M., Lawton, K., Staub, T., and Bassi, B. 1999. Commercial development of elicitors of induced resistance to pathogens. Pages 357-369 in: Induced Plant Defenses Against Pathogens and Herbivores. Biochemistry, Ecology, and Agriculture. A. A. Agrawal, S. Tuzun, and E. Bent, eds. American Phytopathological Society, St. Paul, MN.

39. Thayer, P. L., and Stall, R. E. 1961. Effect of variation in the bacterial spot pathogen of pepper and tomato on control with streptomycin. Phytopathology 81:568-571.

40. Vallad, G. E., and Goodman, R. M. 2004. Systemic acquired resistance and induced systemic resistance in conventional agriculture. Crop Sci. 44:19201934.

41. Vallad, G. E., Pernezny, K. L., Balogh, B., Wen, A. M., Figueiredo, J. F. L., Jones, J. B., Momol, T., Muchovej, R. M., Havranek, N., Abdallah, N., Olson, S., and Roberts, P. D. 2010. Comparison of kasugamycin to traditional bactericides for the management of bacterial spot on tomato. HortScience 45:1834-1840.

42. Walters, D., Walsh, D., Newton, A., and Lyon, G. 2005. Induced resistance for plant disease control: maximizing the efficacy of resistance elicitors. Phytopathology 95:1368-1373.

43. Walters, D. R., and Fountaine, J. M. 2009. Practical application of induced resistance to plant diseases: an appraisal of effectiveness under field conditions. J. Agric. Sci. 147:523-535.

44. Wen, A. M., Balogh, B., Momol, M. T., Olson, S. M., and Jones, J. B. 2009. Management of bacterial spot of tomato with phosphorous acid salts. Crop Prot. 28:859-863.

45. Woodcock, J., Moazed, D., Cannon, M., Davies, J., and Noller, H. F. 1991. Interaction of antibiotics with A- and P-site-specific bases in $16 \mathrm{~S}$ ribosomal RNA. EMBO J. 10:3099-3103. 